\title{
WHITE-CLAWED CRAYFISH IN MUDDY HABITATS: MONITORING THE POPULATION IN THE RIVER IVEL, BEDFORDSHIRE, UK
}

\author{
S. PEAY (1), A. PROUD (2) AND D. WARD (3)
}

(1) Scott Wilson, The Design Innovation Centre, 46 The Calls, Leeds, LE2 7EY, UK. E-Mail: stephanie@crayfish.org.uk

(2) Ivel and Ouse Countryside Project, The Smithy, The Village, Old Warden, Biggleswade, Beds, SG18 9HQ, UK.

E-Mail: amandap@bedsrcc.org.uk

(3) AndrewsWardAssociates, Water Hall Cottage, 48 GreatLane, Reach, Cambs, CB5 0JF, UK. E-Mail: awaecology@reach-village.co.uk

Reçu le 16 juin 2005

Accepté le 2 novembre 2005

Received June 16, 2005

Accepted November 2, 2005

\begin{abstract}
White-clawed crayfish Austropotamobius pallipes are usually associated with stony substrates, tree roots, or refuges in submerged banks. The River Ivel has the last known population of white-clawed crayfish in Bedfordshire. Prior to 2005, much of the bed comprised uniform silt, plus leaf-litter. Stands of reedmace Typha latifolia and other emergent vegetation were localised in less shaded areas. Initial survey results suggested a population at low abundance. A low-cost monitoring strategy was started in 2001 and continued three times a year to 2005, using engineering bricks, which offer artificial refuges. Crayfish are counted when bricks are lifted periodically. De-silting of c. $430 \mathrm{~m}$ river was carried out in February 2005, to improve habitat and to maintain the flood capacity in the channel upstream of a mill weir. Additional bricks were deployed a few weeks in advance of de-silting, then bricks and crayfish were lifted prior to dredging and were returned the next day. Starting upstream, soft, wet mud was dredged out, placed on the bank and searched manually for crayfish. Banks, tree roots and shallow margins were left undisturbed. In all, 4,142 crayfish were found in dredgings from a $430 \mathrm{~m}$ length of the mid channel. Crayfish were strongly associated with emergent vegetation, but many were present below the surface of the silt. Crayfish released in the dredged channel immediately burrowed into the silt retained on the channel margins. Monitoring after dredging showed no change in abundance in the main area with in-bank refuges and lots of bricks, but there was an increase in occupancy of bricks in an area where most crayfish had been in emergent vegetation.
\end{abstract}

Key-words: white-clawed crayfish, habitat, mud, mitigation, monitoring.

\section{ÉCREVISSES À PATTES BLANCHES DANS LES HABITATS BOUEUX : SUIVI DE LA POPULATION DANS LA RIVIÈRE IVEL, BEDFORDSHIRE, ROYAUME-UNI}

\section{RÉSUMÉ}

Les écrevisses à pattes blanches Austropotamobius pallipes sont d'habitude associées à des substrats pierreux, racines d'arbre, ou refuges dans les berges 
submergées. La Rivière Ivel a la dernière population connue d'écrevisse à pattes blanches du Bedfordshire. Avant 2005, une bonne partie du substrat était constituée de boue uniforme et de détritus de feuilles. Les emplacements de roseaux Typha latifolia et d'autre végétation émergente se trouvaient dans des secteurs moins ombragés. Les résultats d'enquêtes initiales ont suggéré une population de faible abondance. Une stratégie à faible coût de suivi des écrevisses à pattes blanches dans les cours d'eau a été mise en œuvre dès 2001, à raison de trois enquêtes annuelles jusqu'en 2005, en utilisant les briques de construction, qui offrent des refuges artificiels. Les écrevisses sont comptées périodiquement en allant soulever les briques. Un désenvasement a été effectué en février 2005 sur environ $430 \mathrm{~m}$ de rivière, pour améliorer l'habitat et maintenir la capacité d'inondation du lit en amont d'un barrage de moulin. Des briques supplémentaires ont été mises en place quelques semaines avant le désenvasement, puis briques et écrevisses ont été enlevées avant le dragage et remises dés le lendemain. En partant de l'amont, la boue douce et mouillée a été draguée, déposée sur la rive, et fouillée manuellement à la recherche d'écrevisses. Les berges, les racines d'arbres et les bordures peu profondes n'ont pas été fouillées. En tout, 4142 écrevisses ont été dénombrées dans les matériaux dragués sur $430 \mathrm{~m}$ de long au milieu du lit. Les écrevisses étaient fortement associées à la végétation émergente, mais beaucoup étaient présentes aussi sous la surface du limon. Les écrevisses relâchées dans le cours d'eau dragué se sont aussitôt ré-enfouies dans le limon déposé sur les bords du cours d'eau. Le suivi réalisé après le dragage n'a pas mis en évidence de modification d'abondance dans le secteur principal avec les refuges en berge et beaucoup de briques, mais il a en revanche permis de constater une augmentation de l'occupation des briques dans un secteur où la plupart des écrevisses étaient précédemment dans la végétation émergente.

Mots-clés : écrevisses à pattes blanches, habitat, amélioration, surveillance.

\section{INTRODUCTION}

The white-clawed crayfish Austropotamobius pallipes can occur in a wide range of habitats in watercourses and still waters. FOSTER (1995) found white-clawed crayfish in hill streams, large rivers and ditches in Wales. They were positively associated with tree cover, tree roots, moss cover (all associated with shaded streams) and water chemistry with slightly elevated nitrate and phosphate. SMITH et al. (1996) also found that the presence and abundance of white-clawed crayfish was correlated with extensive steep, complex banks, with overhanging vegetation and with tree roots projecting into the water. HOLDICH (2003) described siltation as an adverse factor, with crayfish preferring hard substrates to soft, muddy ones, but noted that a wide range of materials could be used as refuges, including tree roots, holes in banks, man-made debris, accumulations of fallen leaves and beds of aquatic vegetation such as water crowfoot Ranunculus spp. and water cress Rorippa nasturtium-aquaticum. PEAY and HIRST (2003) and TERO et al. (2003) described the burrows of white-clawed crayfish in steep submerged banks and crayfish in burrows have been recorded in other studies (HOLDICH et al., 2006).

Despite this, there have been few studies of crayfish in very muddy habitats (HOLDICH et al., 2006). Such conditions are not suitable for manual surveys, which require clear water and safe access to the channel. Crayfish can sometimes be found by netting among submerged fine roots of trees such as alder Alnus glutinosa, but yields tend to be very low compared to those in habitats that are more suitable for manual searches. Trapping can be used, but again may not detect crayfish, or only in very low numbers. There has therefore been a tendency for surveyors to avoid surveys in muddy conditions and for the assumption to be made that white-clawed crayfish are absent, or present only at very low abundance.

The indigenous white-clawed crayfish is decreasing its range in England and Wales, largely due to disease carried by introduced signal crayfish Pacifastacus 
leniusculus (HOLDICH et al., 1999; HOLDICH et al., 2004). This trend has also occurred in Bedfordshire in eastern England. White-clawed crayfish were once common in the River Ivel and tributaries, part of the catchment of the Great Ouse, which drains to The Wash. GREEN and BELLAMY (1999) surveyed over 60 sites in the county in 1999, but found only two with white-clawed crayfish. A further survey of 49 sites on the Rivers Ivel and other tributaries was carried out in 2001, by trapping and netting (PROUD and GREEN, 2001). This confirmed white-clawed crayfish in a tributary of the River Hit and another on the River Ivel. By 2003, however, the site on the Hit had been colonised by signal crayfish and no white-clawed crayfish were found (A. Proud, pers. obs.) This left the population in the River Ivel near Astwick as the only known population in Bedfordshire. An intensive monitoring programme was started in 2001 by the Ivel and Ouse Countryside Project to assess the extent and abundance of the white-clawed crayfish population and, if possible, to conserve it.

This case study reports on the monitoring of the River Ivel population between 2001 and 2005 and describes work undertaken in February 2005, when the river had to be desilted to ensure there was sufficient flood storage capacity in the channel. A comparison of the surveys and the removal of crayfish during dredging shows that muddy habitats can support abundant populations of crayfish.

\section{SITE DESCRIPTION AND METHODS}

The River Ivel in Bedfordshire runs through a low-lying area of relatively flat farmland of arable and grassland (40 $\mathrm{m}$ above sea level). There is an isolated population of white-clawed crayfish near Astwick (Figure 1). The upstream limit appears to be at Taylors Bridge. Upstream of this bridge the channel is heavily modified for drainage and is frequently dredged. The downstream limit appears to be approximately $430 \mathrm{~m}$ downstream at Bowmans Mill, where the river has been widened to create a mill pond, before it flows down a vertical mill weir more than $5 \mathrm{~m}$ high, into a straightened and deepened stretch. The weir is probably at least a partial barrier to the movement of crayfish. In the study area the river is bordered by woodland and amenity grassland on the right (north) bank and by pasture, fallow land and a narrow fringe of riverside trees on the left bank.

By 2004 the study area was a heavily silted and slow-flowing channel 6-8 m wide. Where margins were unshaded and sufficiently consolidated there was a sparse growth of broadleaved plants, with clumps of the tall aquatic grasses Glyceria maxima and Phalaris arundinacea in places. The upstream end of the mill pond had been colonised by a dense stand of Typha latifolia. Much of the channel was shaded by trees and the very soft silt was bare of vegetation, or lightly covered by leaf litter. The most favourable habitat appeared to be where the banks were steep, with exposed fine tree-roots, but even these were largely submerged by silt. Immediately upstream of the weir the riverbanks were faced with old brickwork for about $15 \mathrm{~m}$ on both banks, which provided potentially suitable refuges for crayfish. Elsewhere, banks with potential for refuges for crayfish were estimated at about $15-20 \%$ of the total length.

Initial surveys by netting and trapping in 2001 suggested the population was sparse and localised at Bowmans Mill. The Ivel and Ouse Countryside Project initiated a programme to provide additional refuges and to monitor the population, by placing engineering bricks in the margins of the channel.

The types of refuge used are shown in Figure 2. The hole sizes in the bricks were $10,15,20,30$ or $70 \mathrm{~mm}$ and the number of holes per brick varied accordingly from 21 to 1. The bricks were supported on flat roof tiles, to spread the weight and reduce the rate at which bricks sank into the mud. Bricks were set with clear water back and front, set at right angles to the flow. Initially 22 bricks were used, but this was increased in 2002 

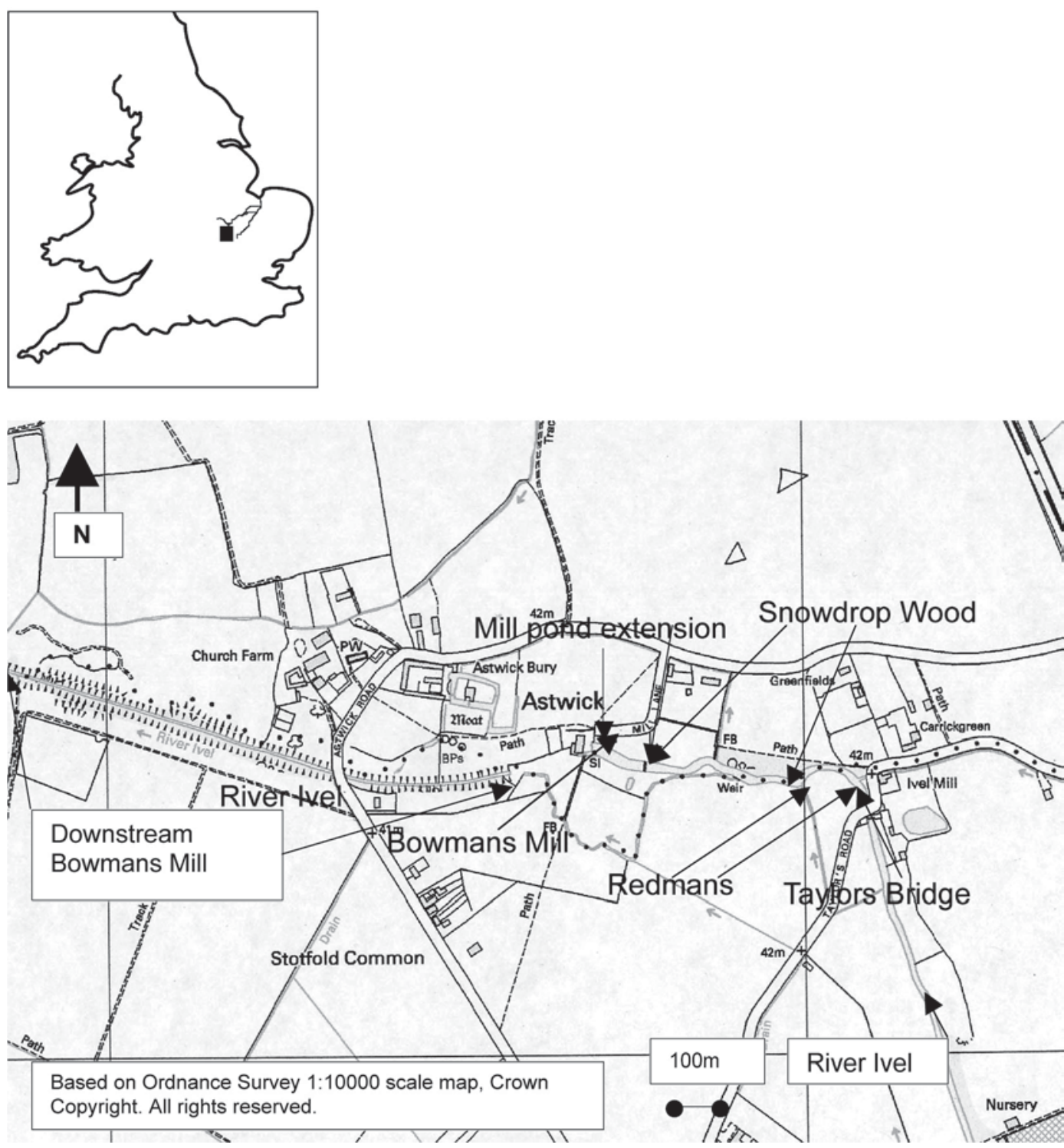

Figure 1

Location of site.

Figure 1

Emplacement du site

and 2003, following the discovery of crayfish at Taylors Bridge. The bricks were inspected 3 times a year in spring, summer and autumn. Crayfish were counted in situ and the bricks and occupying crayfish were returned to the channel. The sex and size of a sample of crayfish was recorded during the inspections in summer in 2003 and 2004.

By 2004 there was concern that progressive siltation would cover all the available refuges in the channel. Furthermore, there was a potential risk of flooding of adjacent land, due to reduced capacity of the channel. The Bedford and River Ouse Internal Drainage Board (IDB), which is responsible for maintaining the river, proposed dredging, but with measures to mitigate the impact on white-clawed crayfish. 

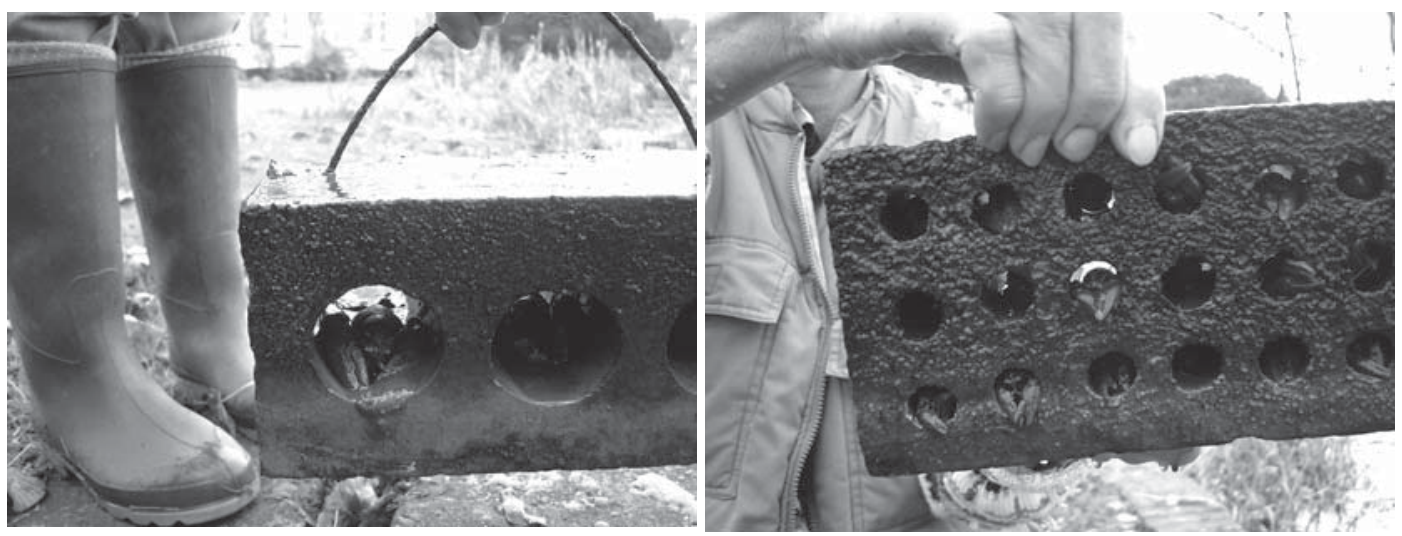

Figure 2

Types of refuge, $3 \mathrm{~cm}$ 3-hole and $1.5 \mathrm{~cm}$ multi-hole brick, with white-clawed crayfish.

\section{Figure 2}

Types de refuge: briques de 3 trous de $3 \mathrm{~cm}$ et brique avec multiples trous de $1,5 \mathrm{~cm}$, avec écrevisses à pattes blanches.

Accordingly, in January 2005 additional bricks were installed at Bowmans Mill, increasing the total to 165 . These were all removed at the start of works (14 ${ }^{\text {th }}$ February 2005) and placed in an inflatable swimming pool half-filled with water. Crayfish were counted but, to minimise disturbance, were not measured or sexed. The water level was reduced by $0.15 \mathrm{~m}$ by the removal of a control board at the mill weir, and then the section of river immediately upstream of the mill weir was dredged. At the upstream end of the mill pond the large bed of Typha was left undredged to provide a silt trap during the next phase of dredging. Crayfish from the mill pond were kept in the pool overnight and observed for a period after dark. By the next day, turbidity had reduced and the bricks and crayfish were returned to the river.

The working direction was determined by the access to the riverbank for machinery. Work was always carried out from one bank with a $360^{\circ}$ slew long-reach tracked excavator. Each bucket of silt was spread in an arc across the available bank, usually less than $0.2 \mathrm{~m}$ deep and examined for crayfish by one to three staff. The silt was not raked, but any crayfish seen emerging out of wet silt were caught by hand and returned to the river into the newly dredged channel. Each morning the spoil from the previous day was checked for any more crayfish. No excavation was carried out within $0.6 \mathrm{~m}$ of either bank, which left tree roots and the brick walls of the mill pond undisturbed. After the dredging between Taylors Bridge and Bowmans Mill a further $400 \mathrm{~m}$ of shaded, silted river was dredged downstream of the major weir and culvert at Bowmans Mill.

Monitoring of occupation of bricks by crayfish was resumed in April 2005, with further monitoring in July and September 2005.

A session of trapping was also carried out in August 2005 (19/08/05), using 53 funnel traps with $4 \mathrm{~mm}$ mesh, baited with sardines in vegetable oil and set for a single night in dry conditions. The habitat type within $1 \mathrm{~m}$ of the trap was noted.

\section{RESULTS}

No crayfish were caught in 6 traps set at Bowmans Mill in 2001, nor again in 2002. In 2001 two surveyors caught 5 crayfish from a $2 \times 20$-minute session of sweep-netting in 
vegetation and roots in the mill pond at Bowmans Mill. The same netting effort in August 2002 returned a similar total of 6 crayfish.

The number of crayfish recorded using the bricks was very much higher than from netting. Results for Bowmans Mill are shown in Figure 3, in each season from autumn 2001 to spring 2005. The total catch is shown, plus the number of bricks (the number of bricks recorded, which may be less than the total set out in the river, due to occasional losses). The minimum number of crayfish recorded (21 in September 2001) was when the lowest number of bricks was offered, whereas in April 2005, with data recorded from 144 bricks, the total number of crayfish found was 856 .

CPUE has been calculated as the average number of crayfish per brick, an average covering all the types in use. Although the number of holes potentially available in the bricks ranged from 1 for tunnels to 21 for $1.5 \mathrm{~cm}$ multi-hole bricks, each new batch added included a range of types and the average CPUE per hole is in proportion to average CPUE per brick. There was considerable variation in CPUE per brick during the study period. The lowest value was 1.5 in autumn 2001 and the highest values (5.1 and 5.2) were from the most recent surveys, immediately before and two months after dredging. CPUE appears to increase; the average CPUE for the samples in winter 2001 to summer 2003 was 2.4, compared to 4.3 for autumn 2003 to spring 2005. An ANOVA test, however, shows there is no significant difference in CPUE in the two periods $(P>0.1)$. There also appears to be a higher CPUE in the winter/spring records, when water is cooler and crayfish are less active, but again the ANOVA test shows the difference is not significant $(P>0.1)$.

Use of 10 bricks in the section between Bowmans Mill and the upstream end of the study area at Taylors Bridge in August 2003 showed a CPUE of 3.3 and confirmed that the population was continuous within the stretch. Downstream of Taylors Bridge, where 11 bricks were used, the catch ranged from 1-9 crayfish in total prior to dredging, a CPUE

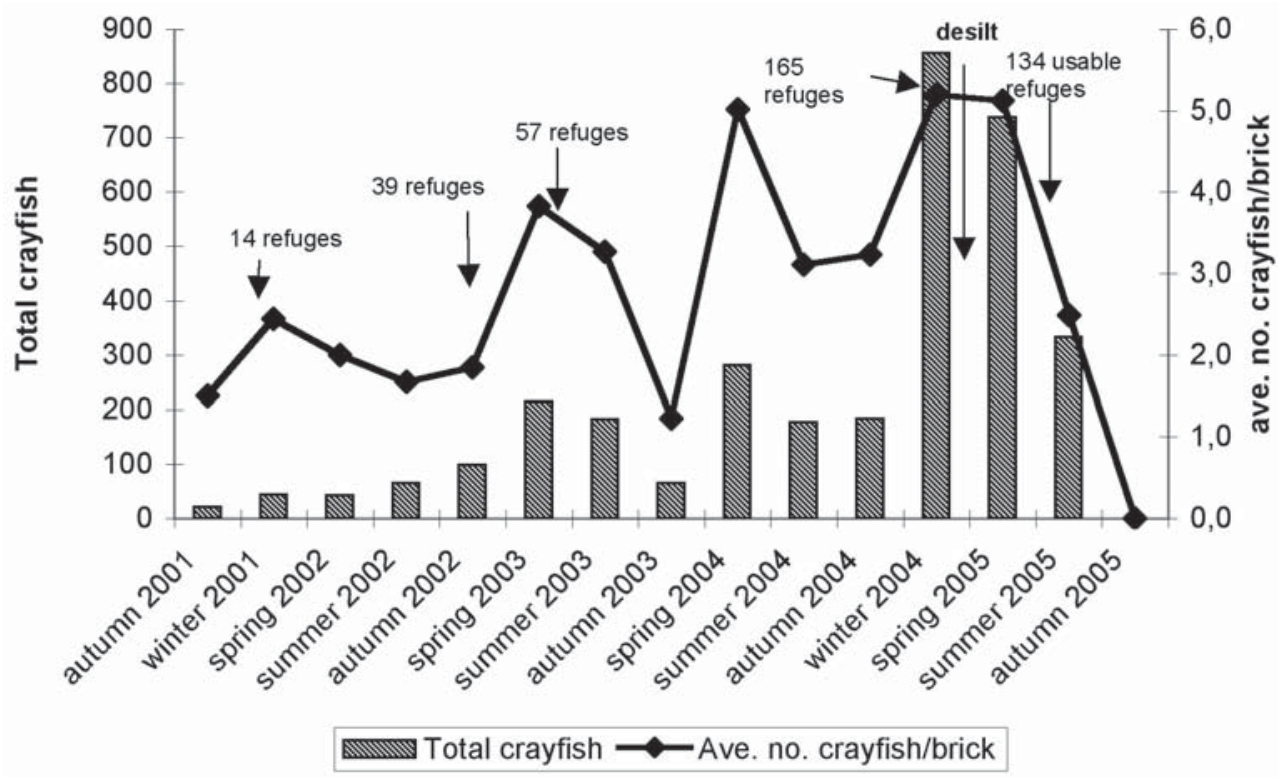

Figure 3

Results of monitoring with bricks, autumn 2001 to autumn 2005.

Figure 3

Résultats de suivi avec les briques, automne 2001 à automne 2005. 
of 0.1-0.8. This was consistently lower than the CPUE recorded at Bowmans Mill. After dredging, the 22 bricks lifted in April 2005 showed 92 crayfish, an increased CPUE of 4.2, similar to that at Bowmans Mill.

A sample of randomly selected bricks was taken in summer 2003 and 2004, providing catches of 73 and 82 crayfish respectively, and the size and sex of crayfish was recorded (Figure 4). Males comprised $44 \%$ of the sample. The modal size class for males and females was $20-29 \mathrm{~mm} \mathrm{CL}$, comprising $38 \%$ of the catch, with $35 \%$ in the $10-$ $19 \mathrm{~mm}$ CL category.

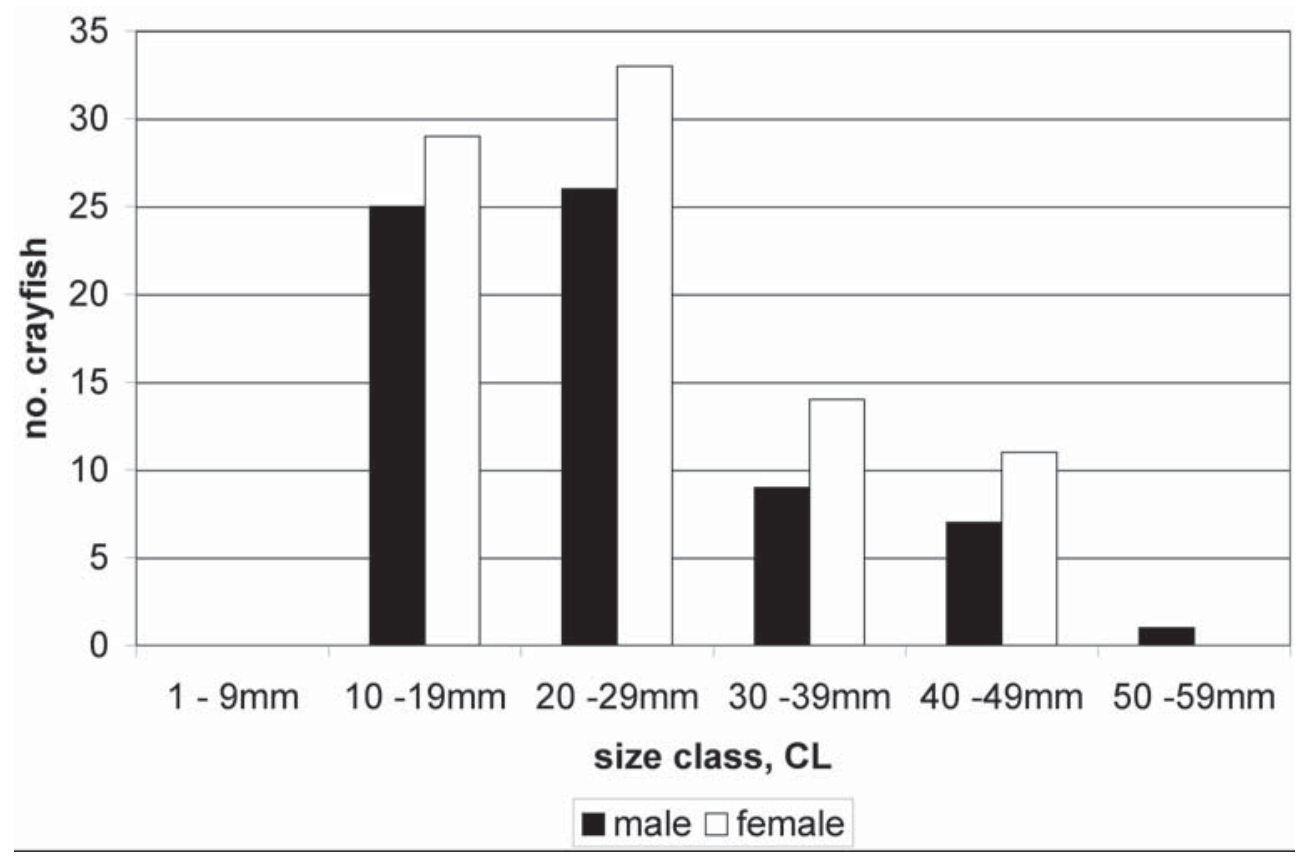

Figure 4

Size distribution of white-clawed crayfish in bricks.

\section{Figure 4}

Distribution en classes de taille d'écrevisses à pattes blanches dans les briques.

The number of crayfish removed from the dredgings in February 2005 is shown in Table I for each day and for subsections (in Figure 1). The total number of crayfish recorded from the $430 \mathrm{~m}$ stretch was 4,142 , equivalent to approximately 9.6 crayfish per linear metre. The total area dredged cannot be estimated accurately, but with some allowance for the undisturbed margins of the channel $(0.6 \mathrm{~m}$ each side) and the greater width in the mill pond, the area is approximately $3,000-3,500 \mathrm{~m}^{2}$. Hence the density of crayfish recovered during dredging is equivalent to $1.2-1.4 \mathrm{~m}^{-2}$.

The variation in abundance within the dredged area was large, however, with the minimum number recorded in a day being 5 and the maximum 1,237 . The work rate varied, with slower progress being made in areas with high yields of crayfish. There was variation in the abundance of crayfish between localised patches with different characteristics. Although crayfish were found beneath the surface in areas of bare silt, numbers were low compared to patches of emergent plants. Phalaris, Glyceria and the outer edges 


\section{Table I}

Crayfish removed and relocated during dredging.

\section{Tableau I}

Écrevisse enlevées et relogées lors du dragage.

\begin{tabular}{|c|c|c|c|c|}
\hline Location & Length & Date & Number & Comments \\
\hline TOTAL at Bowmans Mill & $15 \mathrm{~m}$ & $14 / 02 / 2005$ & 859 & All but 3 were in bricks \\
\hline \multirow[t]{2}{*}{ Mill pond extension } & & $21 / 02 / 2005$ & 25 & Bed of Typha latifolia \\
\hline & & $22 / 02 / 2005$ & 824 & \\
\hline TOTAL of Mill pond extension & $60 \mathrm{~m}$ & & 849 & \\
\hline \multirow[t]{3}{*}{ Snowdrop wood } & & $17 / 02 / 2005$ & 5 & $\begin{array}{l}\text { Few present in Mentha } \\
\text { aquatica or Apium } \\
\text { nodiflorum }\end{array}$ \\
\hline & & $18 / 02 / 2005$ & 211 & \\
\hline & & $21 / 02 / 2005$ & 58 & \\
\hline TOTAL of Snowdrop wood & $245 \mathrm{~m}$ & & 274 & \\
\hline \multirow[t]{2}{*}{ Redman's land } & & 15/02/2005 & 347 & \\
\hline & & $16 / 02 / 2005$ & 56 & \\
\hline TOTAL on Redman's land & $60 \mathrm{~m}$ & & 403 & \\
\hline \multirow[t]{2}{*}{ Taylors Bridge } & & $16 / 02 / 2005$ & 1237 & $\begin{array}{l}\text { In Glyceria maxima and } \\
\text { Phalaris arundinaceae }\end{array}$ \\
\hline & & $17 / 02 / 2005$ & 520 & \\
\hline TOTAL at Taylors Bridge & $50 \mathrm{~m}$ & & 1757 & \\
\hline GRAND TOTAL & $430 \mathrm{~m}$ & & 4142 & \\
\hline
\end{tabular}

of stands of Typha had conspicuously greater numbers of crayfish than patches with Mentha, Apium or bare silt. An initial bucketful from the dense middle of the Typha in the mill pond extension had no crayfish, but when the rest of the Typha was dredged out subsequently, there were over 800 crayfish from a less dense patch about $5 \times 15 \mathrm{~m}$ in extent. The emergent vegetation near Taylors Bridge also produced 100s of crayfish, with over 80 found from a single scoop of the excavator bucket in a stand of Phalaris.

As indicated in Table I, all but 3 of the 859 crayfish removed from $15 \mathrm{~m}$ of the mill pond at Bowmans Mill were in the bricks, not in the bare silt. The number recorded is an under-estimate, because it was noted, after the count, that some holes in the bricks had crayfish in both sides. It is also highly possible that the brickwork held numbers of crayfish. Juveniles and males predominated there. There was, however, a concentration of ovigerous females noted in dredged silt immediately downstream of a small tributary downstream of Taylors Bridge, with relatively few males and juveniles present. In the part of channel where there were lengths of submerged vertical bank with tree roots and due to shading there was very little emergent vegetation, the number of crayfish found in the silt was noticeably lower than elsewhere (Figure 5).

Both adult and juvenile crayfish appeared to be able to climb out onto the surface of the dredged silt, although 1-10 individuals were found each morning, indicating some crayfish must have remained in the silt after the searches of each bucketful and emerged overnight. This was particularly true in areas of deeper silt. When crayfish were released 
in the undisturbed margins of the newly dredged channel, they tended to quickly bury themselves beneath the surface of the remaining silt.

No crayfish were found in the section which was dredged downstream of Bowmans Mill, despite the apparently suitable habitat, with many bankside trees and steep submerged banks.
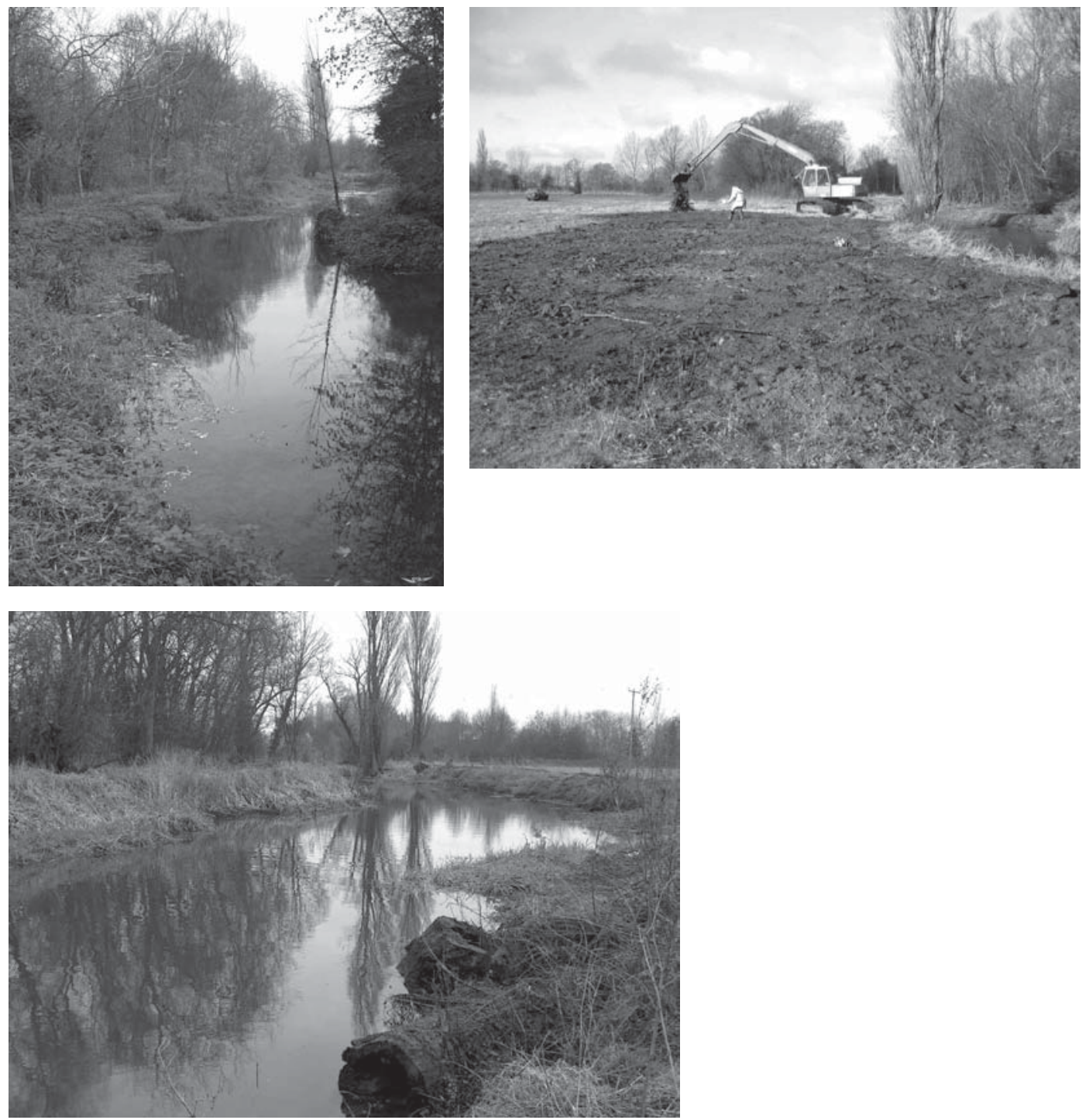

\section{Figure 5}

River Ivel before, during and after dredging.

\section{Figure 5}

Rivière Ivel avant, pendant et après dragage.

By July 2005, much of the mud that had been left at the margins during the dredging operation had redistributed itself within the channel. Many of the bricks were badly silted. Only 134 were usable and many of these were partly silted. The average number of crayfish per brick reduced from 5.0 and 5.1 at Bowmans Mill before and after dredging to 2.5 , although this was still within the range recorded in previous years. A crayfish and associated silt from a brick are shown in Figure 6. 


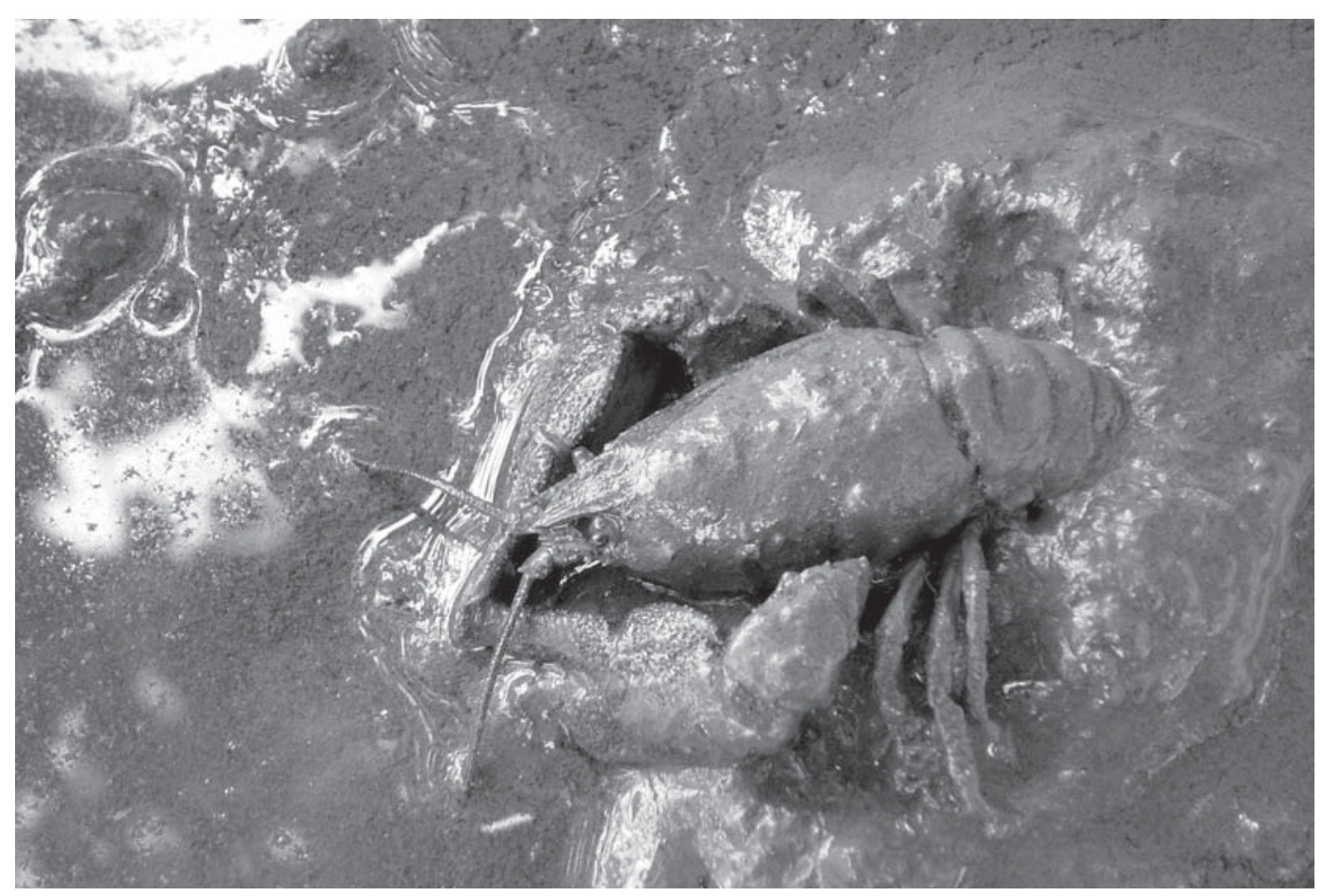

Figure 6

A white-clawed crayfish in mud from a refuge in a brick.

\section{Figure 6}

Une écrevisse à pattes blanches dans la boue d'un trou de briques.

The size distribution of crayfish using different sizes of brick is shown in Figure 7. The median sizes of crayfish using $10 \mathrm{~mm}$ and $30 \mathrm{~mm}$ holes was 14 and $31 \mathrm{~mm} \mathrm{CL}$ respectively. There was no overlap in size range of crayfish; the maximum size in $10 \mathrm{~mm}$ holes was $21 \mathrm{~mm}$ and the minimum size in $30 \mathrm{~mm}$ holes was $24 \mathrm{~mm}$, clearly different. The size ranges in $15 \mathrm{~mm}$ and $20 \mathrm{~mm}$ holes overlap, with median values of 20 (range 5$33 \mathrm{~mm}$ ) and 26 (range 11-35 $\mathrm{mm}$ ) respectively. Although there were more small crayfish in the $15 \mathrm{~mm}$ holes than $20 \mathrm{~mm}$ holes, a Kilmogorov-Smirnov test shows that the maximum difference between the cumulative distributions, $D$, is: 0.3077 with a corresponding $P=0.138$, hence the difference is not significant.

The trapping survey yielded 64 crayfish, an average of 1.2 crayfish per trap night. The modal catch was 2 (34\% of traps); $32 \%$ of traps had no crayfish and only 4 traps $(7.6 \%)$ had 3 or more. The habitat types adjacent to traps are shown in Table 3 . There was a higher catch adjacent to banks with undercutting, tree roots or creviced brick walls and proportionally fewer crayfish adjacent to reedswamp of Phalaris or Glyceria and the difference was significant (chi-squared test, $c h i=11.21$, df $=4, P<0.05$ ).

As this was the last known population of white-clawed crayfish in the county, it was proposed to transfer some crayfish to three new, isolated sites, where it was hoped that newly established populations would be safe from colonisation by signal crayfish, which are spreading slowly upstream towards Astwick. The intention was to move bricks and occupying crayfish to the new sites. When the bricks were lifted for this purpose on 9th September 2005, however, only 37 living crayfish were found at Taylors Bridge. These were moved to a new, enclosed site elsewhere. They have been left undisturbed, but at least one was seen alive in late October 2005 in one of the bricks. No dead crayfish have 


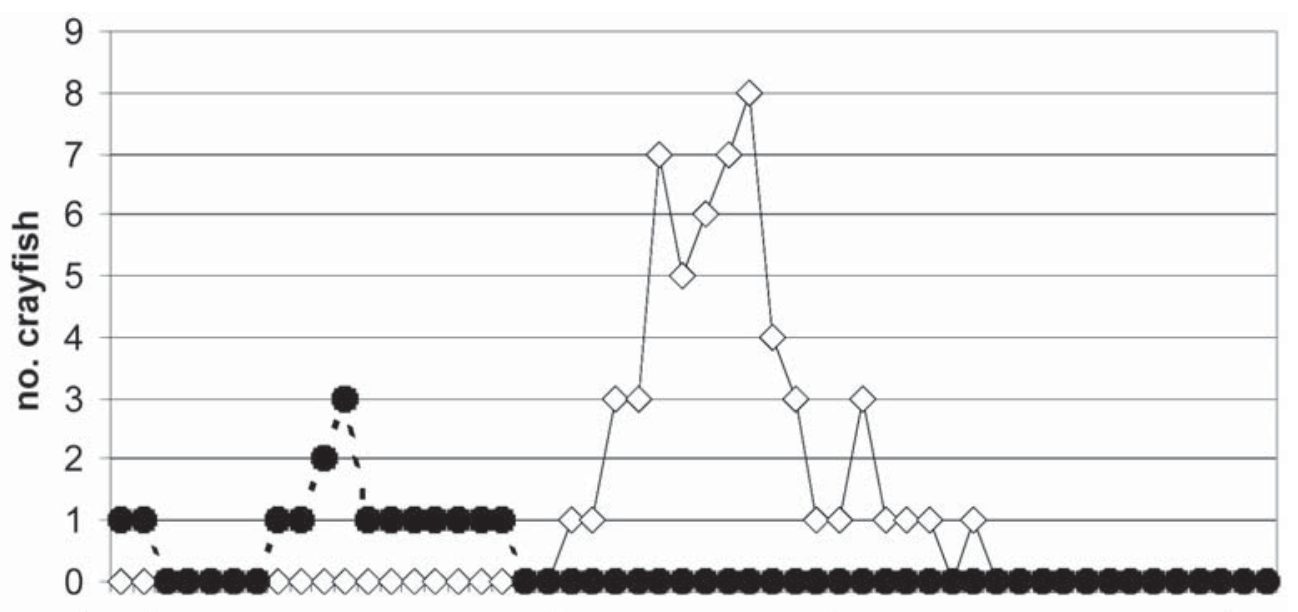

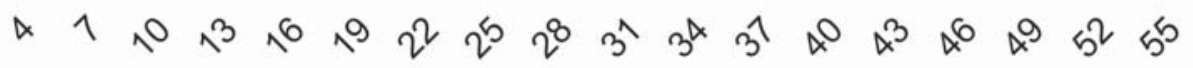

size, $\mathrm{CL} \mathrm{mm}$

$\diamond-30 \mathrm{~mm}$ holes $-\bullet-10 \mathrm{~mm}$ holes

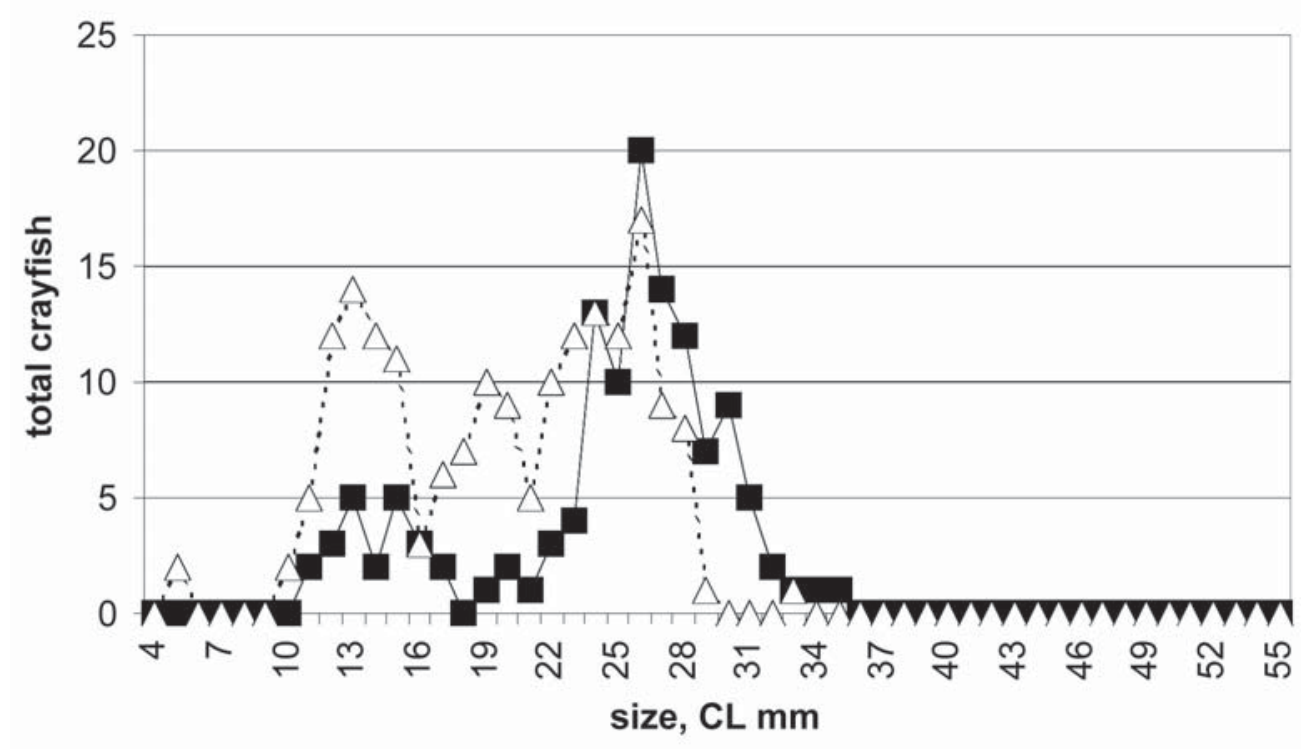

- $20 \mathrm{~mm}$ holes $\cdots \Delta \cdots 15 \mathrm{~mm}$ holes

Figure 7

Size distribution of crayfish (382 total no.) occupying bricks with holes 10, 15, 20 or $30 \mathrm{~mm}$.

Figure 7

Distribution en classes de taille d'écrevisses à pattes blanches (382 no.) dans les briques avec des trous de 10, 15, 20 ou $30 \mathrm{~mm}$.

been found. By contrast there were dead crayfish at Bowmans Mill and a dying one. Samples were taken for investigation. Crayfish plague was suspected, but post mortems and histopathology showed no sign of the disease. Biological water quality samples taken in the study area and upstream showed no significant difference and no sign of any 
pollution. By 23rd September when the autumn survey was carried out, there were no crayfish found within the study area.

\section{DISCUSSION}

The estimated density of $1.2-1.4 \mathrm{~m}^{-2}$ is undoubtedly an under-estimate of the total population in the dredged area. The channel was not dewatered, so a proportion of crayfish will probably have escaped out of the excavator bucket as it was being lifted, by crawling out of disturbed areas into previously worked areas, or by remaining in the undisturbed margins. A proportion of the crayfish dredged out will not have been recovered; because they were unable to crawl out of the drying silt in time, were missed by surveyors, were predated by birds when staff left the site each day; or they walked overland to the river or elsewhere.

The study shows the marked differences in the abundance of crayfish recorded by different methods in the difficult conditions of the site. No crayfish were detected with the relatively small number of traps used (6) in the surveys in 2001 and 2002. Based on the trapping survey in summer 2005 (53 traps), the expectation for 2001 and 2002 would be for two thirds of traps to have had crayfish and for a total catch of approximately 7 . This may indicate an increase in abundance over time, but the number of traps used initially was too small for effective comparison. Netting of tree roots for 40 minutes only produced a few individuals each time, in part because of the difficulty of accessing partially buried roots.

The use of bricks provides an effective method of recording crayfish in all seasons, although because of the lack of any safe access, bricks could only be set in the margins. Unlike trapping, it is most effective at recording crayfish less than $30 \mathrm{~mm} \mathrm{CL}$. After the initial cost of materials and the time required to install the refuges at the start, the monitoring only requires a single visit per dataset. Given the large variation in abundance of crayfish within the channel, it is difficult to assess the extent to which the occupancy level of the bricks reflects the abundance of the population locally, or the availability of refuges of other types within the channel. Bricks become less effective, however, if they fall over or silt up.

In many cases, the crayfish were observed to have wedged themselves in place in a hole and could not easily be dislodged. It was sometimes necessary to wait until the crayfish chose to emerge. Indications are that crayfish have a preference for holes that approximately match their body size, with small individuals avoiding large holes. This is probably a way of increasing their resistance to high flows, or attempted predation by fish.

There is some indication that if better refuges are available, white-clawed crayfish prefer those to bare silt. At Bowmans Mill, where there are crevices in old brickwork and many additional bricks were provided, almost all the crayfish recovered before or during dredging were in bricks, rather than the silt. Likewise, where there was complex bank available, with plenty of tree roots and the potential to make burrows in banks, crayfish were noticeably less abundant in the silted channel, although the suitable bank was limited in extent. Where the margins were so silted that there were minimal in-bank refuges, crayfish burrowed among the roots of emergent plants and also into bare mud, as some crayfish were dredged out of the extensive sections with copious mud but no emergent plants.

It is surprising that no white-clawed crayfish were found in the dredging of a further $400 \mathrm{~m}$ of shaded channel downstream of the Bowmans Mill weir. It is possible that whiteclawed crayfish were present in this section, but only occupied the refuges within banks, such that none appeared in the dredgings, but this is unlikely, given the large number 
$(4,142)$ rescued from a similar length of watercourse immediately upstream. Several bricks have been deployed downstream of the culvert for extended periods, but have not been occupied. It appears that the weir and the long culvert prevent white-clawed crayfish from colonising or recolonising this section, or alternatively, unknown factors downstream make the stretch unsuitable. No signal crayfish were found to have moved up into the section, although they are known to be present several kilometres downstream in the lower reaches of the River Ivel.

There was no change in the recorded abundance of crayfish at Bowmans Mill after dredging, possibly because most of the crayfish were already using the old brickwork and bricks, both of which remained after dredging. By contrast, there was an increase in CPUE at Taylors Mill from an average of 0.5 to 4.2 per brick. This may be because most of the crayfish were occupying the emergent vegetation and after its removal, bricks became a more important substitute. In addition, most of the crayfish removed from the Taylors Bridge and Redmans subsections were released downstream of the road bridge close to the bricks, which may have increased occupancy, albeit perhaps temporarily. Constriction of the channel by the culvert of the road bridge increases the velocity locally and this may make it less favourable than some of the slower-flowing areas downstream.

Based on dredging, there appeared to be a distinct preference for Phalaris, Typha and Glyceria, compared to the broadleaved marginal plants. A possible reason is the structure of the plants. The stout buried stems of reeds would facilitate burrowing and help stabilise the silt. The reeds also have continuous air spaces (aerenchyma), which provide oxygen into the root zone. Many studies have investigated oxygen transport from aquatic plants into wetlands (e.g. MOORHEAD and REDDY, 1988, JACKSON and ARMSTRONG 1999, JESPERSEN et al., 1998). CALLAWAY and KING (1996) found Typha raised soil oxygen in wetlands by $2-4 \mathrm{mg} \mathrm{l}^{-1}$ at $11-12^{\circ} \mathrm{C}$, compared to the near anoxic conditions without it. STEINBERG and COONROD (1994) also demonstrated the oxidation of the root zone by Typha latifolia, through changes in dissolved oxygen and redox potential and showed Phalaris arundinacea also created localised aerobic conditions, though it had less effect on redox than Typha. Estimates of released oxygen are typically around 0.01 to $0.1 \mathrm{~g} \mathrm{~m}^{-2} \mathrm{~d}^{-1}$, although much higher rates of loss can be produced for short periods. Still water over a silt surface can contribute $3 \mathrm{~g} \mathrm{~m}^{-2} \mathrm{~d}^{-1}$ to the sediments and the biochemical oxygen demand from the silt, from natural breakdown of leaf litter, is typically around 0.01 to $0.1 \mathrm{~g} \mathrm{~m}^{-2} \mathrm{~d}^{-1}$. Consequently, there tends to be an aerobic zone in the root zone and at the surface of silt, even though below the surface the silt may be anoxic.

This aerobic influence at the surface of silt will extend into burrows, such that a crayfish probably only needs to ventilate a burrow lightly to maintain sufficiently aerobic conditions. McMAHON (2002) describes the compensatory regulation to increase the efficiency of oxygen transfer in crayfish via haemocyanin. The oxygen-binding characteristics of haemocyanin are species-specific, but McMAHON cites studies on crabs in which the variant of haemocyanin has been shown to vary over time in response to seasonal variations in dissolved oxygen. If similar responses occur in crayfish, it may be that crayfish in muddy habitats are able to cope better with low oxygen than those resident in well-aerated, stony streams.

Movement of water may be important to crayfish, perhaps for aeration, or to help clear expelled silt from the burrows. Although it could not be quantified, there appeared to be more crayfish in the areas immediately downstream of inflows, such as the tributary drain at Taylors Bridge, the mill bypass downstream of Taylors Bridge and field drains (D. Warrd, pers. obs.) There also appeared to be few crayfish in the densest areas of Typha, possibly due to less movement of water, or because of the mass of vegetation partly impedes the movement of crayfish. 
GHERARDI et al. (2001) found that, in a clean stream, white-clawed crayfish fed preferentially in the habitat patches of a few tens of square centimetres to a few square metres that were richest in carbon and nitrogen, mainly vegetable debris and mosscovered roots and they foraged over as short distances as possible. In productive, muddy habitats leaf litter is present in great abundance, as are the other macroinvertebrates that feed on detritus, so the distance that crayfish need to cover in foraging is likely to be small. It is possible that this reduces the response of white-clawed crayfish to baited traps. Availability of refuges and interactions between crayfish may be more important factors in determining the density and distribution of crayfish in the channel in muddy habitats.

By contrast to the results from dredging, the trapping survey in summer 2005 suggested that the dense stands of reedswamp were significantly less favourable to crayfish. Alternatively, crayfish may have been present in similar abundance in the reedswamp, but less attracted to the traps, which were set just beyond the fringe of vegetation. This might reflect food availability in the reedswamp. These traps had to be set further from the bank and they were in an area where silt, which had eroded from the dug faces along the margins, had been re-deposited by summer 2005. This was especially so in the mill pond. This recently deposited silt might have been less consolidated than older deposits retained in the margins elsewhere and perhaps more difficult for crayfish to walk on the surface.

Relatively high abundance of white-clawed crayfish may be found in muddy habitats, where preliminary surveys by manual survey, netting or trapping record only low numbers. Future survey efforts in muddy streams may identify hitherto unknown populations of crayfish in the UK.

When mitigation measures are taken to reduce the impact of works on white-clawed crayfish, especially during dredging, the need to search the dredgings slows machine work to about half that of normal operations and there is a further increased cost when two or more people are searching the dredgings. Spreading the silt thinly enough to assist the retrieval of crayfish (Figure 5) may be limited by the space available on the bank, reducing the efficiency of removal and further reducing the work rate.

In terms of minimising impact on the indigenous white-clawed crayfish, the priority is to retain complex bank structure, fine tree roots and patches of small woody detritus. Where in-bank habitat is limited, the crayfish are likely to be concentrated at the margins of reedswamp; Typha latifolia, Phalaris arundinacea, Glyceria maxima and probably Phragmites australis and Sparganium erectum. It is likely that these are most suitable when the water is deep enough to amply cover crayfish and the stands are not too dense, although the evidence for this is limited as yet. An understanding of these small-scale habitat preferences may encourage methods of working that retain some habitat diversity in maintained channels, to the benefit of white-clawed crayfish and other species.

The reason for the demise of the population is unknown. It appears that crayfish plague was not responsible. Porcelain disease (thelohaniasis) occurred in $6.3 \%$ of the population in bricks in July 2005 and $18.8 \%$ of the larger animals recorded in trapping in August 2005, but this could not account for the rapid mortality in early September 2005. Whether the population is now extinct, or some individuals have survived is not known. It is certainly a major setback for the conservation of the white-clawed crayfish in this area of eastern England. Nonetheless, the Ivel and Ouse Countryside Project proposes to monitor the bricks next year, in the hope that at least some individuals have survived and the population will recover over time.

\section{ACKNOWLEDGEMENTS}

The Ivel and Ouse Countryside Project is funded by the Bedfordshire Rural Communities Charity. English Nature provided the bricks and other materials for the 
project. Thanks are given to the Bedfordshire and Ivel Internal Drainage Board; especially to project manager Bob Spendlove, who also spent many hours rescuing crayfish; machine operator Phil Hopkins for his skilful work on site and to Jonathon Wallis for his efforts in rescuing crayfish. Volunteers from the Ivel and Ouse Countryside Project kindly assisted in moving and replacing bricks at Bowmans Mill. Ian McGill, veterinary officer at the Institute of Zoology, Zoological Society of London carried out histology and post mortems. Staff of the Environment Agency carried out biological water quality sampling.

\section{REFERENCES}

CALLOWAY R.M., KING L., 1996. Temperature-driven variation in substrate oxygenation and the balance of competition and facilitation. J. Ecology, 77, 1189-1195.

FOSTER J., 1995. Factors influencing the distribution and abundance of the crayfish Austropotamobius pallipes (Lereboullet) in Wales and the Marches, UK. Freshwater Crayfish, 8, 78-98.

GREEN J., BELLAMY G., 1999. White-clawed crayfish survey, March 1999. unpublished report. Bedfordshire Wildlife Trust.

GHERARDI F., ACQUISTAPACE P., SANTINI G., 2001. Foraging by a threatened species - the white-clawed crayfish, Austropotamobius pallipes. Archiv für Hydrobiologie, 152, 339-351.

HOLDICH D.M., SIBLEY P., PEAY S., 2004. The white-clawed crayfish - a decade on. British Wildlife, 15, 153-164.

HOLDICH D.M., 2003. Ecology of the White-clawed Crayfish. Conserving Nature 2000 Rivers Ecology Series No. 1. English Nature, Peterborough. 17 p.

HOLDICH D.M., PEAY S., FOSTER J., HILEY P.D., BRICKLAND J.H., 2006. Studies on the white-clawed crayfish (Austropotamobius pallipes) associated with muddy habitats. Bull. Fr. Pêche Piscic., 380-381, 1055-1078.

HOLDICH D.M., ROGERS W.D., REYNOLDS J.D., 1999. Crayfish in the British Isles. In: GHERARDI, F. and HOLDICH D.M. (eds.) Alien Crayfish in Europe. How to make the best of a bad situation? Balkema, Rotterdam, 221-232.

JACKSON M.B., ARMSTRONG W., 1999. Formation of aerenchyma and the process of plant ventilation in relation to soil flooding and submergence. Plant Biology, 1, 274287.

JESPERSEN D.N., SORRELL B.N., BRIX H., 1998. Growth and root oxygen release by Typha latifolia and its effects on sediment methanogenesis. Aquatic Botany, 6, 165-180.

McMAHON B.R., 2002. Physiological adaptation to environment. In: HOLDICH D.M. (ed.) Biology of Freshwater Crayfish. Blackwell Science. 702 p., 327-376.

MOORHEAD K.K., REDDY K.R., 1988. Oxygen transport through selected aquatic macrophytes. J. Environmental Quality, 17, 138-142.

PEAY S., HIRST D., 2003. A monitoring protocol for white-clawed crayfish in the UK. HOLDICH D.M. \& SIBLEY P.J. (eds), 2003. Management \& Conservation of Crayfish. Proceedings of a conference held of $7^{\text {th }}$ November 2002. Environment Agency, Bristol. 217 p., 39-63.

PROUD A., GREEN J., 2001. The Ivel Valley White-clawed Crayfish Survey, 2001. unpublished report, Ouse and Ivel Countryside Project. 5 p. 
SMITH G.R.T., LEARNER M.A., SLATER F.M., FOSTER J., 1996. Habitat features important for the conservation of the native crayfish Austropotamobius pallipes in Britain. Biological Conservation, 75, 239-246.

STEINBERG S.L., COONROD H.S., 1994. Oxidation of the root-zone by aquatic plants growing in gravel-nutrient solution culture. J. Environmental Quality, 23, 907-913.

TERO C., HOLDICH D.M., SMITH P., KITE N., LONGFIELD R., 2003. White-clawed crayfish Austropotamobius pallipes in the River Witham, Lincolnshire. In: HOLDICH D.M. \& SIBLEY P.J. (Eds) 2003. Management \& Conservation of Crayfish. Proceedings of a conference held of 7th November 2002. Environment Agency, Bristol. 217 p., 159-168. 